\title{
A DESIGUALDADE BRASILEIRA NO SÉCULO XX: PASSADO, MODERNIDADE E EDUCAÇÃO COMO FATORES EXPLICATIVOS ${ }^{1}$
}

\author{
FERREIRA, Walace ${ }^{2}$
}

\begin{abstract}
Carlos Antônio Costa Ribeiro analisa a complexa persistência da desigualdade social brasileira no século XX.

O primeiro ponto tem a ver com a industrialização. Com ela, o Brasil se tornou urbano, numa transformação rápida, mas sem planejamento. Muitos dos filhos da sociedade rural, desigual em sua formação, vivenciaram o peso da origem ao migrarem para as cidades, seja através do preconceito de base racial e/ou geográfica, seja pela falta de conhecimentos técnicos para se empregarem nas indústrias crescentes. Analisando as PNADs de 1973, 1982, 1988 e 1996, Ribeiro conclui que se os filhos de trabalhadores rurais tivessem vindo de famílias menos pobres e se a estrutura agrária brasileira não fosse historicamente tão desigual, o número de pessoas que chegaram às classes médias e altas seria maior.
\end{abstract}

Em segundo lugar, o crescimento do sistema educacional foi lento. Nas décadas de 60 e 70, auge da industrialização, as universidades e as escolas de nível secundário cresceram mais que o ensino básico. Com isso, a maior parte da população pobre e migrante não conseguiu ingressar no sistema escolar básico. Apenas a partir da década de 90 verifica-se um efetivo aumento desse segmento de ensino no Brasil. A educação, assim, permaneceu como fonte de acesso à reduzida parcela privilegiada da sociedade brasileira.

O terceiro fator relevante, que conjugou-se com os anteriores para a preservação das desigualdades sociais, consiste nas dificuldades que o país enfrentou no que tange à modernização do setor produtivo. Coexistiram o desenvolvimento de empresas capitalistas e públicas de tecnologia avançada, e um setor financeiro moderno, com setores tradicionais na indústria e nos serviços (inclusive com forte informalidade) e baixos salários. Foi no trabalho informal, aliás, que parcela da população oriunda do campo foi se alojando.

O conturbado crescimento econômico manifestou seus efeitos negativos, sobretudo, nas décadas de 80 e 90 . Apesar do fim da ditadura militar, "a democracia política não viria acompanhada da democracia social, uma vez que as desigualdades permaneceram altas" (pg. 36).

Dessa maneira, no século $X X$, o país deixou para trás uma sociedade rural e semicolonial, dominada por grandes plantações, passando a uma sociedade predominantemente urbana e como parques industriais e centros comerciais modernos, mas não isolados de características tradicionais de subdesenvolvimento. Impactos presentes nas transformações do início do século XXI, e que, de muitas maneiras, ainda nos caracteriza.

\footnotetext{
${ }^{1}$ RIBEIRO, Carlos Antônio Costa. Estrutura de classe e mobilidade social no Brasil. Bauru, SO: Edusc, 2007.

${ }^{2}$ Doutor em Sociologia (IESP/UERJ). Professor da Secretaria Estadual de Educação do Rio de Janeiro (SEEDUC).

E-mail: walaceuerj@yahoo.com.br
} 